\title{
Hubungan Pengetahuan, Sikap dan Iklan Susu Formula dengan Pemberian ASI Ekslusif di Wilayah Puskesmas Rawat Inap Cempaka Kota Banjarbaru
}

\author{
Relationship of Knowledge, Attitude and Advertising of Formula Milk With Exclusive Breast \\ Feeding in Puskesmas Rawat Inap cempaka In The Banjarbaru City \\ Netty $^{1 *}$, Siti Rabiathul ${ }^{2}$, Nurul Indah Qariati ${ }^{3}$ \\ ${ }^{1}$ Fakultas Kesehatan Masyarakat \\ 2Universitas Islam Kalimantan Muhammad Arsyad Al Banjari \\ *korespondensi : netty.uniska@gmail.com
}

\begin{abstract}
Exclusive breastfeeding rate in South Kalimantan is only $51.18 \%$ of what should be $70 \%$. Factors that inhibit exclusive breastfeeding are the lack of mother's knowledge of exclusive breastfeeding excellence, mother's attitude towards exclusive breastfeeding, and incessant milk formula advertising. The aim of this research is to know the relationship of knowledge, attitude and advertising of formula milk with Exclusive Breast Feeding in Cempaka Rawat Inap Puskesmas of 2018. Method of research of analytic survey with cross sectional approach. The population is all mothers who have babies aged 6-24 months which amounted to 435 people. Sample of 81 people. Sampling using technique Purposive sampling. The statistical test is Chi square test. The results showed that the most breastfeeding was not exclusive breastfeeding as much as 42 people (51.9\%). Knowledge of respondents at most is quite as much as 43 people (53.1\%). The most positive attitude is 46 people (56.8\%). Infant formula advertising in mothers showed that most respondents were interested in formula milk ads as much as 48 people (59.3\%). There is knowledge relation ( $p$-value $=0,012<\alpha 0,05)$, there is relationship of attitude ( $p$-value $=0,000<\alpha 0,05)$. There is a formula milk advertising relationship ( $p$-value $=0,000<\alpha 0.05$ ). It is hoped that mothers can increase their knowledge, awareness about the importance of exclusive breastfeeding, and are not interested in formula milk advertising despite offering attractive promotions and prizes
\end{abstract}

Keywords: Knowledge; Attitudes; Formula Milk Ads; Exclusive Breast Feeding

\section{Pendahuluan}

ASI Eksklusif adalah pemberian ASI saja kepada bayi umur 0 sampai usia 6 bulan. Presentasi ASI Eksklusif Nasional hanya sebesar $(37,3 \%)$ dimana presentasi terendah terdapat pada provinsi Nusa tenggara Barat $(20,3 \%)$ dan tertinggi pada provinsi Bangka belitung (56,7\%). Kalimantan selatan menduduki urutan ke 7 tertinggi, yaitu diatas angka nasional (47\%). Riskesdas 2018 (1) Berdasarkan data Dinas Kesehatan Kota Banjarbaru (2017) Dinas Kesehatan Kota Banjarbaru memiliki 8 puskesmas, diantaranya adalah puskesmas Rawat inap Cempaka dengan cakupan ASI Eksklusif terendah yaitu urutan ke 8 hanya sebesar 39,86\%, jauh dibawah yang ditetapkan oleh Dinkes kota Banjarbaru yaitu sebesar $70 \%$ Dinkes Kota Banjarbaru(2). Puskesmas rawat inap Cempaka membawahi 4 kelurahan dengan 28
Posyandu. Jumlah ibu yang mempunyai bayi umur 6-24 bulan sebesar 435 orang (3). Hasil penelitian Rohmawati W,dkk 2017(4) hanya sekitar 39,4\% ibu Memeberikan ASI Eklusif. Begitu pula dengan penelitian Ningsih DA, 2018 (5) hanya $30 \%$ ibu yang memberikan ASI Eksklusif . Menurut Lestari $\mathrm{RR}, 2018(6)$ Ada beberapa faktor yang mempengaruhi pemeberian ASI Eksklusif diantaranya yaitu pengetahuan, sikap ibu terhadap pemberian ASI Eksklusif, gencarnya iklan susu formula. Hasil Penelitain (6) ada hubungan Pengetahuan dengan pemberian ASI Eklusif pada ibu di Wilayah Puskesmas Tapung Perawatan Kabupaten Kampar Riau. Penelitian Julian S,2018 (7) ada hubungan sikap dengan pemebrian ASI Eksklusif Di Wilayah kerja Puskesmas Darussalam Kecamatan Medan Petisah. Penelitian Nislawati, 2018 (8) ada hubungan keterpaparan iklan susu formula 
dengan pemeberian ASI pada bayi di kelurahan Langgini wilayah kerja Puskesmas Bangkinang , kabupaten Kampar. Berdasarkan uraian diatas maka peneliti tertarik untuk mengmbil judul "Hubungan pengetahuan, sikap dan iklan susu formula dengan pemberian ASI Eksklusif di wilayah Puskesmas Rawat Inap Cempaka Tahun 2018".

\section{Metode Penelitian}

Metode penelitian yang digunakan adalah survey analitik dengan pendekatan cross sectional study. Populasi penelitian ini adalah seluruh ibu yang mempunyai bayi umur 6-24 bulan di Puskesmas Rawat Inap Cempaka Tahun 2017 yang berjumlah 435 orang. Pengambilan data penelitian pada tanggal 16 - 20 Juli 2018. Sampel berjumlah 81 orang,. Hasil diperoleh melalui wawancara menggunakan kuesioner. Analisis data yang digunakan adalah analisis univariat dan analisis bivariat. Uji statistik yang dipakai adalah uji Chi square test yaitu menguji Hubungan antara variable bebas dan variable terikat dengan menggunakan derajat kepercayaan 95\%.

\section{Hasil Penelitian}

1. Karakteristik responden yang di teliti meliputi umur anak, jumlah anak, pekerjaan dan pendidikan ibu.

a. Umur Anak

Karakteristik responden berdasarkan umur anak adalah sebagai berikut:

Tabel 1. Distribusi Frekuensi Responden Menurut Umur Anak di wilayah Puskesmas Rawat Inap Cempaka Kota Banjarbaru

\begin{tabular}{cll}
\hline Umur & $\mathbf{n}$ & $\mathbf{( \% )}$ \\
\hline $6-12$ & 55 & 67,9 \\
Bulan & & \\
\hline $13-24$ & 26 & 32,1 \\
Bulan & & \\
\hline Jumlah & 81 & 100 \\
\hline
\end{tabular}

Berdasarkan Tabel 1 hasil penelitian menunjukkan bahwa umur anak responden paling banyak yaitu di katergori umur 6-12 bulan sebanyak 55 orang $(67,9 \%)$,

b. Jumlah Anak

Karakteristik responden berdasarkan jumlah anak adalah sebagai berikut:
Tabel 2 Distribusi Frekuensi Responden Menurut Jumlah Anak di wilayah Puskesmas Rawat Inap Cempaka Kota Banjarbaru

\begin{tabular}{ccc}
\hline Jumlah Anak & $\mathbf{n}$ & $\mathbf{( \% )}$ \\
\hline 1 Orang & 28 & 34,6 \\
\hline 2 Orang & 42 & 51,8 \\
\hline 3 Orang & 9 & 11,1 \\
\hline 4 Orang & 2 & 2,5 \\
\hline Jumlah & 81 & 100 \\
\hline
\end{tabular}

Berdasarkan Tabel 2 hasil penelitian menunjukkan bahwa jumlah anak responden paling banyak berada di kategori 2 orang sebanyak 42 orang $(51,8 \%)$,

c. Pekerjaan

Karakteristik responden berdasarkan pekerjaan adalah sebagai berikut:

Tabel 3 Distribusi Frekuensi Responden Menurut Pekerjaan di wilayah Puskesmas Rawat Inap Cempaka Kota Banjarbaru

\begin{tabular}{ccc}
\hline Pekerjaan & $\mathbf{n}$ & $(\%)$ \\
\hline Tidak Bekerja & 41 & 50,6 \\
\hline Swasta & 40 & 49,4 \\
\hline Jumlah & 81 & 100 \\
\hline
\end{tabular}

Berdasarkan Tabel 3 hasil penelitian menunjukkan bahwa responden paling banyak yaitu kategori tidak bekerja sebanyak 41 orang $(50,6 \%)$,

\section{d. Pendidikan}

Karakteristik responden berdasarkan pendidikan adalah sebagai berikut:

Tabel 4 Distribusi Frekuensi Responden Menurut Pendidikan di wilayah Puskesmas Rawat Inap Cempaka Kota Banjarbaru

\begin{tabular}{ccc}
\hline Pendidikan & $\mathbf{n}$ & $(\%)$ \\
\hline Dasar & 44 & 54,3 \\
\hline Menengah & 37 & 45,7 \\
\hline Tinggi & 0 & 0 \\
\hline Jumlah & 81 & 100 \\
\hline
\end{tabular}

Berdasarkan Tabel 4 hasil penelitian menunjukkan bahwa pendidikan responden paling banyak yaitu setingkat pendidika dasar sebanyak 44 orang $(54,3 \%)$,

\section{Analisis Univariat}

a. Gambaran Pemberian ASI Eksklusif di wilayah Puskesmas Rawat Inap Cempaka Kota Banjarbaru Tahun 2018 
Tabel 5 Distribusi Frekuensi Pemberian ASI Eksklusif di wilayah Puskesmas Rawat Inap Cempaka Kota Banjarbaru

\begin{tabular}{cccc}
\hline Pemberian ASI Eksklusif & $\mathbf{n}$ & (\%) \\
\hline ASI Eksklusif & 39 & 48,1 \\
\hline Tidak ASI Eksklusif & 42 & 51,9 \\
\hline Jumlah & 81 & 100
\end{tabular}

Berdasarkan Tabel 5 hasil penelitian menunjukkan bahwa paling banyak ibu termasuk kategori tidak ASI Eksklusif sebanyak 42 orang $(51,9)$

b. Gambaran pengetahuan ibu tentang pemberian ASI Eksklusif di wilayah Puskesmas Rawat Inap Cempaka Kota Banjarbaru

Tabel 6 Distribusi Frekuensi pengetahuan ibu tentang Pemberian ASI Eksklusif di wilayah Puskesmas Rawat Inap Cempaka Kota Banjarbaru

\begin{tabular}{ccc}
\hline Pengetahuan & $\mathbf{n}$ & $(\%)$ \\
\hline Baik & 16 & 19,7 \\
\hline Cukup & 43 & 53,1 \\
\hline Kurang & 22 & 27,2 \\
\hline Jumlah & 81 & 100 \\
\hline
\end{tabular}

Berdasarkan Tabel 6 hasil penelitian menunjukkan bahwa pengetahuan responden paling banyak kategori cukup sebanyak 43 orang $(53,1 \%)$, tetapi masih ada masuk dalam kategori kurang sebesar $27,2 \%$

c. Gambaran sikap ibu tentang pemberian

ASI Eksklusif di wilayah Puskesmas

Rawat Inap Cempaka Kota Banjarbaru

Tabel 7 Distribusi Frekuensi sikap ibu tentang pemberian ASI Eksklusif di wilayah Puskesmas Rawat Inap Cempaka Kota Banjarbaru

\begin{tabular}{ccc}
\hline Sikap & $\mathbf{n}$ & $\mathbf{( \% )}$ \\
\hline Positif & 46 & 56,8 \\
\hline Negatif & 35 & 43,2 \\
\hline Jumlah & 81 & 100 \\
\hline
\end{tabular}

Berdasarkan Tabel 7 hasil penelitian menunjukkan bahwa sikap paling banyak kategori positif sebanyak 46 orang $(56,8 \%)$,

d. Gambaran iklan susu formula pada ibu di wilayah Puskesmas Rawat Inap Cempaka Kota Banjarbaru

Tabel 8 Distribusi Frekuensi iklan susu formula pada ibu di wilayah Puskesmas Rawat Inap Cempaka Kota Banjarbaru

\begin{tabular}{ccc}
\hline Iklan susu formula & $\mathbf{n}$ & $\mathbf{( \% )}$ \\
\hline Tertarik & 48 & 59,3 \\
\hline Tidak Tertarik & 33 & 40,7 \\
\hline Jumlah & 81 & 100 \\
\hline
\end{tabular}

Berdasarkan Tabel 8 hasil penelitian menunjukkan bahwa responden paling banyak kategori tertarik dengan iklan susu formula sebanyak 48 orang $(59,3 \%)$,

\section{Analisis Bivariat}

Analisis bivariat adalah hasil analisis hubungan antara variabel bebas dengan variabel terikat dengan menggunakan uji Chi-square.

a. Hubungan pengetahuan dengan pemberian ASI Eksklusif di wilayah Puskesmas Rawat Inap Cempaka Kota Banjarbaru

Tabel 9 Hubungan pengetahuan dengan pemberian ASI Eksklusif di wilayah Puskesmas Rawat Inap Cempaka Kota Banjarbaru

\begin{tabular}{ccccccc}
$\begin{array}{c}\text { Penget } \\
\text { ahuan }\end{array}$ & \multicolumn{2}{c}{$\begin{array}{c}\text { Asi } \\
\text { Eksklusif }\end{array}$} & \multicolumn{2}{c}{$\begin{array}{c}\text { Tidak Asi } \\
\text { Eksklusif }\end{array}$} & \multicolumn{2}{c}{ Total } \\
\cline { 2 - 7 } & $\mathbf{n}$ & $\%$ & $\mathbf{n}$ & $\%$ & $\mathbf{n}$ & $\%$ \\
\hline Baik & 11 & 68,8 & 5 & 31,3 & 16 & 100 \\
\hline Cukup & 23 & 53,3 & 20 & 46,5 & 43 & 100 \\
\hline Kurang & 5 & 22,7 & 17 & 77,3 & 22 & 100 \\
\hline Jumlah & 39 & 48,1 & 42 & 51,9 & 81 & 100 \\
\hline \multicolumn{5}{c}{$p$-value $=0,012<\alpha 0,05$} \\
\hline
\end{tabular}

Berdasarkan Tabel 9 diketahui bahwa responden yang berpengetahuan baik berjumlah 16 orang, yang memberikan ASI Eksklusif sebanyak 11 orang $(68,8 \%)$ dan yang tidak memberikan ASI Eksklusif sebanyak 5 orang $(31,3 \%)$, sedangkan responden yang berpengetahuan cukup sebanyak 43 orang, yang memberikan ASI Eksklusif sebanyak $(53,3 \%)$ dan yang tidak memberikan ASI Eksklusif sebanyak (46,5\%), dan responden yang berpengetahuan kurang sebanyak 22 orang $(77,3)$ yang memberikan ASI Eksklusif sebanyak 5 orang $(22,7 \%)$ dan yang tidak memberikan ASI Eksklusif sebanyak 17 orang $(77,3 \%)$.

Hasil uji statistik dengan Chi-square di dapatkan nilai $p$-value $=0,012<\alpha 0,05$ maka Ho di tolak dan Ha di terima artinya ada hubungan pengetahuan dengan pemberian ASI Eksklusif di wilayah Puskesmas Rawat Inap Cempaka Tahun 2018. 
b. Hubungan sikap dengan pemberian ASI Eksklusif di wilayah Puskesmas Rawat Inap Cempaka Kota Banjarbaru

Tabel 10 Hubungan sikap dengan pemberian ASI Eksklusif di wilayah Puskesmas Rawat Inap Cempaka Kota Banjarbaru

\begin{tabular}{|c|c|c|c|c|c|c|}
\hline \multirow[t]{2}{*}{ Sikap } & \multicolumn{2}{|c|}{$\begin{array}{c}\text { Asi } \\
\text { Eksklusif }\end{array}$} & \multicolumn{2}{|c|}{$\begin{array}{l}\text { Tidak Asi } \\
\text { Eksklusif }\end{array}$} & \multicolumn{2}{|c|}{ Total } \\
\hline & $\mathbf{n}$ & $\%$ & $\mathbf{n}$ & $\%$ & $\mathbf{n}$ & $\%$ \\
\hline Positif & 30 & 65,2 & 16 & 34,8 & 46 & 100 \\
\hline Negatif & 9 & 25,7 & 26 & 74,3 & 35 & 100 \\
\hline Jumlah & 39 & 48,1 & 42 & 51,9 & 81 & 100 \\
\hline \multicolumn{7}{|c|}{$00<\alpha 0,05$} \\
\hline
\end{tabular}

Berdasarkan Tabel 10 diketahui bahwa responden yang memiliki sikap positif sebanyak 46 orang, yang memberikan ASI Eksklusif sebanyak 30 orang $(65,2 \%)$ dan yang tidak memberikan ASI Eksklusif sebanyak 16 orang (34,8\%), sedangkan responden yang memiliki sikap negatif sebanyak 35 orang, yang memberikan ASI Eksklusif sebanyak 9 orang (25,7\%) dan yang tidak memberikan ASI Eksklusif sebanyak 26 orang $(74,3 \%)$.

Hasil uji statistik dengan Chi-square di dapatkan nilai $p$-value $=0,000<\alpha 0,05$ maka Ho di tolak dan Ha di terima artinya secara ada hubungan sikap dengan pemberian ASI Eksklusif di wilayah Puskesmas Rawat Inap Cempaka Tahun 2018.

c. Hubungan iklan susu formula dengan pemberian ASI Eksklusif di wilayah Puskesmas Rawat Inap Cempaka Kota Banjarbaru

Tabel 11 Hubungan iklan susu formula dengan pemberian ASI Eksklusif di wilayah Puskesmas Rawat Inap Cempaka Kota Banjarbaru

\begin{tabular}{lccccccc}
\hline \multirow{2}{*}{$\begin{array}{c}\text { Iklan } \\
\text { Susu } \\
\text { Formula }\end{array}$} & \multicolumn{2}{c}{$\begin{array}{c}\text { Asi } \\
\text { Eksklusif }\end{array}$} & \multicolumn{2}{c}{$\begin{array}{c}\text { Tidak Asi } \\
\text { Eksklusif }\end{array}$} & \multicolumn{2}{c}{ Total } \\
\cline { 2 - 7 } & $\mathbf{n}$ & $\%$ & $\mathbf{n}$ & $\%$ & $\mathbf{n}$ & $\%$ \\
\hline Tertarik & 1 & 25,0 & 36 & 75,0 & 48 & 100 \\
& 2 & & & & & \\
\hline Tidak & 2 & 81,8 & 6 & 18,2 & 33 & 100 \\
Tertarik & 7 & & & & & \\
\hline Jumlah & 3 & 48,1 & 42 & 51,9 & 81 & 100 \\
& 9 & & & & & \\
\hline \multicolumn{5}{c}{$p$-value $=0,012<\alpha 0,05$} \\
\hline
\end{tabular}

Berdasarkan Tabel 11 diketahui bahwa responden tertarik dengan iklan susu formula sebanyak 48 orang, yang memberikan ASI Eksklusif sebanyak 12 orang $(25,0 \%)$ dan yang tidak memberikan
ASI Eksklusif sebanyak 36 orang $(75,0 \%)$, sedangkan responden yang tidak tertarik dengan iklan susu formula sebanyak 33 orang, yang memberikan ASI Eksklusif sebanyak 27 orang $(81,8 \%)$ dan yang tidak memberikan ASI Eksklusif sebanyak 6 orang $(18,2 \%)$.

Hasil uji statistik dengan Chi-square di dapatkan nilai $p$-value $=0,000<\alpha 0,05$ maka Ho di tolak dan Ha di terima artinya ada hubungan iklan susu formula dengan pemberian ASI Eksklusif di wilayah Puskesmas Rawat Inap Cempaka

\section{Pembahasan}

1. Gambaran Pemberian ASI Eksklusif di wilayah Puskesmas Rawat Inap Cempaka Kota Banjarbaru

Berdasarkan Tabel 5 ibu yang tidak ASI Eksklusif lebih banyak yaitu sebesar 42 orang $(51,9 \%)$. Hasil penelitian ini sejalan dengan penelitian Rachmaniah,2014 (9) Ibu yang tidak memberikan ASI Eksklusif terhadap bayi sebesar $77.8 \%$. Hasil penelitian ini juga sejalan dengan penelitian Julian S, 2018 (7) ibu yang tidak ASI eksklusif sebesar $62,2 \%$. Alasan ibu tidak memeberikan ASI eksklusif karena hari-hari pertama ASI belum keluar sehingga bayi langsung diberi sussu formula, ibu sudah harus bekerja sebelum bayi berusia 6 bulan. Ada sebesar 49,4 ibu bekerja, serta bayi tidak mau mengisap ASI.

2. Gambaran pengetahuan ibu tentang pemberian ASI Eksklusif di wilayah Puskesmas Rawat Inap Cempaka Kota Banjarbaru

Berdasarkan Tabel 6 bahwa pengetahuan responden terbanyak yaitu kategori cukup sebanyak 43 orang $(53,1 \%)$, tetapi mashi ada yang berpengetahuan kurang yaitu sebesar 22 orang (27,2\%)

Hasil penelitian ini sejalan dengan penelitian Ida LM,dkk 2015 (10) paling banyak Responden Mempunyai pengetahuan kategori cukup yaitu $54,2 \%$.

Menurut Notoatmodjo pengetahuan adalah merupakan hasil tahu dan ini terjadi setelah orang mengadakan peinderaan terhadap suatu objek seperti membaca, mendengar dan sehingga semakin banyak ibu melakukanhal tersebut akan semakin bertambah pengetahuan 
3. Gambaran sikap ibu tentang pemberian ASI Eksklusif di wilayah Puskesmas Rawat Inap Cempaka Kota Banjarbaru

Berdasarkan Tabel 7 didapatkan bahwa paling banyak kategori sikap positif sebanyak 46 orang $(56,8 \%)$, Hasil penelitian ini juga sejalan dengan penelitian (10) didapatkan hasil bahwa ibu yang kategori bersikap positif 50,8 \%.Menurut (11) sikap adalah Kesiapan atau kesadaran Untuk bertindak, sikap bukan merupakan Tindakan tetapi Presposis tindakan.

4. Gambaran iklan susu formula pada ibu di wilayah Puskesmas Rawat Inap Cempaka Kota Banjarbaru

Berdasarkan table 8 didapatkan bahwa responden paling banyak termasuk kategori tertarik dengan iklan susu formula sebanyak 48 orang $(59,3 \%)$, Hasil penelitian ini sejalan dengan penelitian (8) responden lebih banyak termasuk kategori tertarik terhadap iklan susu formula (54.5\%).

Iklan susu formula dapat diartikan sebagai komunikasi atau pesan yang menawarkan produk susu formula kepada masyarakat, baik melalui media cetak maupun elektronik Berbagai jenis iklan susu formula, mulai dari menunjukan bayi yang montok dan sehat, anak kecil yang pintar dan pemberani, bahkan ada juga yang menghadirkan tenaga kesehatan didalam iklan tersebut. Hal ini yang mengakibatkan masyarakat menjadi kurang percaya akan kemampuan ASI dalam memenuhi kebutuhan bayi dan tertarik untuk memberikan susu formula pada bayi (8).

\section{Hubungan pengetahuan dengan pemberian ASI Eksklusif di wilayah Puskesmas Rawat Inap Cempaka Kota Banjarbaru}

Berdasarkan Tabel 9 didapatkan responden yang berpengetahuan baik berjumlah 16 orang, yang memberikan ASI Eksklusif sebanyak 11 orang $(68,8 \%)$ dan yang tidak memberikan ASI Eksklusif sebanyak 5 orang $(31,3 \%)$, sedangkan responden yang berpengetahuan cukup sebanyak 43 orang, yang memberikan ASI Eksklusif sebanyak $(53,3 \%)$ dan yang tidak memberikan ASI Eksklusif sebanyak $(46,5 \%)$ dan responden yang berpengetahuan kurang sebanyak 22 orang $(77,3)$ yang memberikan ASI Eksklusif sebanyak 5 orang $(22,7 \%)$ dan yang tidak memberikan ASI Eksklusif sebanyak 17 orang (77,3\%). Hasil uji statistik dengan Chisquare di dapatkan nilai $p$-value $=0,012<\alpha$ 0,05 maka Ho di tolak dan Ha di terima artinya secara statistik ada hubungan pengetahuan dengan pemberian ASI Eksklusif di wilayah Puskesmas Rawat Inap Cempaka Kota Banjarbaru

$$
\text { Penelitian Widiyanto }
$$

menunjukkan ada hubungan pengetahuan ibu pemberian ASI eksklusif $(p=0,000)$. $(p<$ $0,05)$ Artinya seseorang yang tidak pernah atau sedikit mendapatkan informasi cenderung memiliki tingkat pengetahuan kurang, Sehingga kuarang jiga akan pengetahuan tentang ASI Eksklusif. Penelitian ini sejalan dengan penelitian (4), Ada hubungan antara tingkat pengetahuan ibu tentang ASI dengan tindakan ASI eksklusif $(p=0,008)$.

Begitu pula penelitian yang dilakukan oleh Robiwala (14) ada hubungan yang signifikan antara tingkat pengetahuan ibu dengan pemberian ASI eksklusif di wilayah kerja Puskesmas Kokap 1 Kabupaten kulon Progo, Yogyakarta $(p=0,005)$.

Menurut Maryunani (15) pengetahuan berhubungan dengan pemberian ASI Eksklusif. Pengetahuan yang rendah akan mempengaruhi seseorang untuk tidak memberikan ASI Eksklusif kepada anaknya karena mereka tidak mengetahui manfaat dari ASI Eksklusif. Pengetahuan yang rendah tentang manfaat ASI Eksklusif dapat diperoleh dari pengalaman pribadi, mereka yang mempunyai anak lebih dari satu ketika anak pertama diberikan susu formula kecenderungan anak selanjutnya akan diberikan susu formula lagi itu artinya anak tidak mendapatkan ASI Eksklusif, begitu sebaliknya ketika ibu sudah mempunyai pengalaman yang baik dalam memberikan ASI Eksklusif dengan benar cenderung akan memberikan ASI Eksklusif lagi selanjutnya. Dengan pengalaman inilah nantinya pengetahuan tersebut akan semakin meningkat dan menjadi dasar dalam pembentukan sikap sehingga dapat mendorong minat atau motivasi untuk selalu memberikan ASI Eksklusif. Oleh karena itu perlu adanya peningkatan pengetahuan agar mereka lebih mengetahui manfaat apa saja dari memberikan ASI Eksklusif kepada anak dan ibu sendiri. Untuk itu diperlukan 
konseling dan promosi kesehatan melalui media yang menarik seperti ceramah, tanya jawab, leaflet. Menurut Notoatmodjo (11) bahwa tindakan seseorang individu termasuk kemandirian dan tanggung jawabnya dalam berperilaku sangat dihubungkan oleh domain kognitif atau pengetahuan. Perilaku individu akan lebih langgeng dan bertahan lama apabila didasari oleh pengetahuan yang baik.

6. Hubungan sikap dengan pemberian ASI Eksklusif di wilayah Puskesmas Rawat Inap Cempaka Kota Banjarbaru

Berdasarkan Tabel 10 didapatkan bahwa responden yang memiliki sikap positif sebanyak 46 orang, yang memberikan ASI Eksklusif sebanyak 30 orang $(65,2 \%)$ dan yang tidak memberikan ASI Eksklusif sebanyak 16 orang (34,8\%), sedangkan responden yang memiliki sikap negatif sebanyak 35 orang, yang memberikan ASI Eksklusif sebanyak 9 orang (25,7\%) dan yang tidak memberikan ASI Eksklusif sebanyak 26 orang $(74,3 \%)$.

Hasil uji statistik dengan Chi-square di dapatkan nilai $p$-value $=0,000<\alpha 0,05$ maka Ho di tolak dan $\mathrm{Ha}$ di terima artinya secara statistik ada hubungan sikap dengan pemberian ASI Eksklusif di wilayah Puskesmas Rawat Inap Cempaka Kota Banjarbaru Tahun 2018. Hasil penelitian ini sejalan dengan penelitian (13) Hasil penelitian menunjukan bahwa ada hubungan sikap ibu $p=0,001,(p<0,05)$ yang berarti bahwa ada berhubungan sikap dengan pemberian asi eksklusif pada bayi di wilayah kerja Puskesmas Kotobangon Kecamatan Kotamobagu Timur. Jadi Sikap yang baik akan membuat responden memberikan ASI Eksklusif sebesar 7,47 kali di bandingkan dengan Sikap yang kurang baik.

Menurut (13) Sikap berhubungan sebab akibat dengan pemberian ASI Eksklusif. Sikap negatif dari seseorang akan mempengaruhi pemberian ASI Eksklusif. Dalam hal ini responden dalam menentukan sikap terhadap pemberian ASI Eksklusif tidak terlepas dari pengetahuan, jadi dari hasil pengetahuan yang baik akan menghasilkan sikap yang positif dalam melakukan pemberian ASI Eksklusif. Untuk itu diperlukan pengetahuan pengetahuan melalui promosi kesehatan sehingga dengan meningkatnya pengetahuan tersebut nantinya akan menjadi dasar dalam penentuan sikap dan sikap yang baik itulah nantinya akan mendorong minat seseorang untuk memberikan ASI Eksklusif. Karena apabila seseorang telah berpengetahuan baik maka mereka akan cenderung bersikap positif. Namun sebaliknya apabila seseorang bersikap negatif mereka lebih cenderung menganggap bahwa tidak perlu memberikan ASI Eksklusif kepada anaknya.

7. Hubungan iklan susu formula dengan pemberian ASI Eksklusif di wilayah Puskesmas Rawat Inap Cempaka Kota Banjarbaru

Berdasarkan Tabel 11 didapatkan bahwa responden yang tertarik dengan iklan susu formula sebanyak 48 orang, yang memberikan ASI Eksklusif sebanyak 12 orang $(25,0 \%)$ dan yang tidak memberikan ASI Eksklusif sebanyak 36 orang (75,0\%), sedangkan responden yang tidak tertarik dengan iklan susu formula sebanyak 33 orang, yang memberikan ASI Eksklusif sebanyak 27 orang $(81,8 \%)$ dan yang tidak memberikan ASI Eksklusif sebanyak 6 orang $(18,2 \%)$.

Hasil uji statistik dengan Chi-square di dapatkan nilai $p$-value $=0,000<\alpha 0,05$ maka Ho di tolak dan Ha di terima artinya secara statistik ada hubungan iklan susu formula dengan pemberian ASI Eksklusif di wilayah Puskesmas Rawat Inap Cempaka Kota Banjarbaru. Hasil penelitian ini sejalan dengan penelitian Rohmawati (4) diketahui bahwa ada hubungan ketertarikan iklan susu formula dengan pemberian ASI eksklusif hasil nilai p $0,000<0,05$, berarti terdapat hubungan antara hubungan ketertarikan iklan susu formula dengan pemberian ASI eksklusif.

Menurut (4) Ketertarikan seseorang terhadap Iklan susu formula akan menimbulkan suatu dampak pada keputusan membeli susu formula sehingga ibu memutuskan untuk memberikan susu formula kepada anaknya sehingga ibu tidak memberikan ASI Eksklusif. Iklan dapat mempengaruhi pola dan perilaku ibu. Pengaruh itu bisa positif dan bisa negatif. Iklan susu formula yang bagus dapat dengan mudah beredar di kalangan para ibu yang sedang menyusui. Responden tertarik dengan iklan susu formula dikarenakan 
sebagian responden belum mengetahui tentang manfaat ASI Eksklusif. ibu sangat mudah mendapatkan informasi mengenai susu formula untuk bayi usia 0-6 bulan dari media cetak seperti dari televisi, majalah, surat kabar dan media elektornik seperti Handphone, internet dan lain nya. Semakin sering ibu terpapar iklan susu formula ditambah kemasan dari susu formula menarik dan promo hadiah-hadiah yang diberikan produsen iklan susu dan kandungan yang terdapat didalam kemasan susu seperti tambahan kandungan zat gizi (AA, DHA, Omega 3, Laktoferin, Prebiotik), apalagi seorang ibu yang tertarik dan menginginkan anak seperti bintang iklan di susu tersebut dan ditambah susu formula mudah didapatkan serta harganya murah akan membuat ibu semakin tertarik dan memutuskan untuk membeli dan memberikan kepada anaknya.

\section{Kesimpulan}

1. Responden Yang tidak ASI Eksklusif lebih banyak yaitu sebesar 42 orang $(51,9 \%)$ dari pada ASI Eksklusif yaitu sebanyak 39 orang $(48,1 \%)$.

2. Pengetahuan responden paling banyak yaitu kategori cukup sebanyak 43 orang $(53,1 \%)$. tetapimasih ada yang berpengetahuan kurang 22 Orang $(22,7 \%)$

3. Sikap positif lebih banyak yaitu 46 orang $(56,8 \%)$ dari sikap negatif yaitu sebanyak 35 orang $(43,2 \%)$.

4. Responden yang tertarik dengan iklan susu formula lebih banyak yaitu 48 orang $(59,3 \%)$ dari responden yang tidak tertarik dengan iklan susu formula sebanyak 33 orang $(40,7 \%)$.

5. Ada hubungan pengetahuan dengan pemberian ASI Eksklusif di wilayah Puskesmas Rawat Inap Cempaka Kota Banjarabaru, dengan nilai $p$-value $=$ $0,012<\alpha 0,05$.

6. Ada hubungan sikap dengan pemberian ASI Eksklusif di wilayah Puskesmas Rawat Inap Cempaka Kota Banjarbaru, dengan nilai $p$-value $=0,000<\alpha 0,05$.

7. Ada hubungan iklan susu formula dengan pemberian ASI Eksklusif di wilayah Puskesmas Rawat Inap Cempaka Kota Banjarbaru, dengan nilai $p$-value $=0,000<\alpha 0,05$.

\section{Daftar Pustaka}

1. Riset Kesehatan Dasar (Riskesdas 2018) Proporsi ASI Eksklusif

2. Dinas Kesehatan Kota Banjarbaru. Laporan Tahunan Dinas Kesehatan Kota Banjarbaru, 2018.

3. Puskesmas Rawat Inap Cempaka. Laporan Tahunan Puskesmas Cempaka Tahun 2018

4. Rohmawati W, dkk, 2017 Karakteristik Iklan Susu formula Dengan pemberian ASI Eksklusif Oleh ibu menyusui di Klaten

5. Ningsih DA, 2018. Faktor-faktor Yang memepengaruhi Pemberian ASI Eksklusif tahun 2018.

6. RR Lestari 2018 Faktor-faktor yang berhubungan Pemeberian ASI Eksklusif Pada Ibu Di Wilayah Puskesmas Tapung parawatan Kabupaten Kampar. Jurnal Obsesi Vol 2. N0 2018

7. Juliani,S, 2018. Hubungan pengetahuan, Sikap, dan dukungan tenaga Kesehatan dengan keberhasilan ASI Eksklusif di Wilayah kerja Puskesmas Darussalam Kecamatan Petisah.

8. Nislawati, 2018. Hubungan keterpaparan Iklan Susu formula Dengan Pemeberian ASI Eksklusif pada Bayi Di Kelurahan Lenggini Wilayah kerja Puskesmas Bangkinang Kota Kabupaten Kampar.

9. Rachmaniah, 2104 Hubungan Tingkat Pengetahuan ibu tentang ASi dengan tindakan ASI Eksklusif. Fakultas Kedokteran Universitas Muhammadiyah Surakarta.

10. Ida LM, dkk 2015 Determinan Pemeberian ASI Eklusif Oleh lbu Multifara Di Kabupaten Jeneponto.. Jurnal MKMI 2015

11. Notoatmodjo. Metodologi Penelitian Kesehatan, Jakarta: Rineka Cipta; 2010

12. Notoatmojo, Metodologi Penelitian Kesehatan, Jakarta Rineka Cipta 2012

13. Widiyanto.2012. Hubungan Pendidikan dan Pengetahuan lbu tentang ASI Eksklusif dengan Sikap terhadap Pemberian ASI Eksklusif. Fakultas Kedokteran Universitas Muhammadiyah Semarang. Di akses 21 Juli 2018.

14. Robiwala. 2014. Hubungan Tingkat Pengetahuan Ibu tentang ASI Eksklusif dengan Pemberian ASI saja di Wilayah 
15. Maryunani, Anik. Inisiasi Menyusui Dini, ASI Eksklusif dan Manajemen Laktasi. Jakarta : CV. Trans Info Media ; 2014 